\title{
Bilateral Agreements and Fair Trade Practices: A Policy Analysis of the Colombia-U.S. Free Trade Agreement (2006)
}

\author{
KEVIN J. FANDL ${ }^{2}$
}

\section{ABSTRACT}

This article brings to the attention of those public servants involved in the design and negotiation of free trade agreements between the United States and developing countries, such as Colombia, the potential benefits and drawbacks of negotiating in a bilateral forum. Rather than critiquing the free trade agreement for its particular provisions, this article examines the U.S. policy of negotiating bilaterally with developing countries as opposed to multilaterally in the world trade system and what effects such an approach might have on the economic development of the latter. Using an incremental policy analysis, the article critiques the bilateral approach in terms of economic development and fair trade negotiations using the recent Colombia-U.S. trade agreement as a case study. The article concludes that a bilateral approach that is disconnected from a broader multilateral context may be detrimental to developing countries and recommends increased oversight of such agreements by the World Trade Organization to ensure a higher degree of fairness.

Keywords: Free Trade Agreements ${ }_{i}$ Economic Development $_{i}$ Trade $_{i}$ Bilateral $_{i}$ Multilateral.

1 This article was originally published by the Yale Journal of Human Rights and Development Law (Vol. 10 Page 64) in 2007. Cite as 10 Yale J. H.R. \& Dev. L. 64 (Spring 2007). Este artículo fue publicado originalmente por el Journal de Derechos Humanos y Desarrollo de la Universidad de Yale en 2007.

Kevin J. Fandl, Bilateral Agreements and Fair Trade Practices: A Policy Analysis of the U.S.-Colombia Free Trade Agreement, Yale Journal of Human Rights and Development Law, 10 Yale J. H.R. \& Dev. L. 64 (Spring 2007). Para citar el artículo: FANDL, K. (2014). "Bilateral Agreements and Fair Trade Practices A Policy Analysis of the Colombia-U.S. Free Trade Agreement (2006)", en Revista Con-texto, no. 42, pp. 77-96. DOI: http:// dx.doi.org/10.18601/01236458.n42.07

2 Kevin J. Fandl, J.D., Ph.D. Assistant Professor (Research Track) Fox School of Business, Temple University Department Legal Studies in Business. Email: kevin.fandl@temple.edu 


\section{ACUERDOS BILATERALES Y PRÁCTICAS JUSTAS DE INTERCAMBIO DE COMERCIO: UN ANÁLISIS AL TRATADO DE LIBRE COMERCIO DE COLOMBIA Y ESTADOS UNIDOS (2006)}

\section{RESUMEN}

Este artículo pretende ilustrar a aquellos servidores públicos que están involucrados en el diseño y en la negociación de tratados de libre comercio entre Estados Unidos y países en desarrollo, como es el caso de Colombia, acerca de los posibles beneficios e inconvenientes de negociar en un foro bilateral. Aquí no se busca criticar ningún tratado, sino examinar la política estadounidense de negociar bilateralmente con países en desarrollo versus multilateralmente en un sistema de intercambio mundial, y los efectos que pueden traer estas circunstancias en el desarrollo económico. Motivo por el cual el autor critica la utilización de tratados bilaterales, caso reciente entre Colombia y Estados Unidos, por los efectos que este tiene en el desarrollo económico del país más débil y por la poca igualdad y justicia que existen en el momento de negociar el intercambio de bienes y servicios. Concluye el autor que el escenario bilateral completamente desconectado de un mucho más amplio contexto multilateral puede ir en detrimento para el desarrollo de los países y recomienda mayor vigilancia sobre estos tratados por parte de la OMC (Organización Mundial del Comercio/World Trade Organization) para asegurar un mayor grado de justicia.

Palabras clave: Tratado de Libre Comercio; Desarrollo económico; Intercambio; Bilateral, Multilateral.

\section{INTRODUCTION}

After two years of negotiations and attempts to secure a workable agreement, Colombia and the United States signed a bilateral trade agreement on February 27, 2006. This was a momentous occasion for both countries as Colombia is the third largest Latin American economy and it plays a significant role in U.S. foreign policy. The agreement solidifies many of the trading practices that were in place since 1991 under the Andean Trade Preferences Act (ATPA), which was set to expire in December of 2006, making the timing of this agreement ideal.

In part, the agreement represents a failure on the part of the Bush Administration to secure a Free Trade Area of the Americas, which had been under negotiation since $1998^{3}$. Instead, the U.S. chose to negotiate bilateral agreements with the four Andean countries, Colombia, Bolivia, Ecuador and Peru, crafting unique arrangements for the specific demands and economic resources of each individual country. 
Although the agreement with Colombia has not yet been made law, as it must first be ratified by the U.S. Congress, its supporters offer unquestionable approval of the final terms and it is likely to be codified soon. Alvaro Uribe, President of Colombia, said, "this deal isn't about winners and losers. There are just winners" ${ }^{\prime 4}$. U.S. Trade Representative Robert Portman said of the deal, "[t]he agreement will help foster economic development in Colombia and contribute to efforts to counter narco-terrorism, which threatens democracy and regional stability ${ }^{\prime \prime}$. Economists, industry leaders and politicians alike have expressed positive analyses of this arrangement.

The agreement is beneficial for U.S. businesses that work with Latin America or that intend to in the future ${ }^{6}$. But is this the best arrangement for Colombia? Will this agreement bring economic growth to the Colombian economy, and will that growth reach the impoverished majority? This paper will explore the use of bilateral trade agreements as a general public policy, seen through the eyes of both the dominant and the subordinate parties to the agreement. It will then explore the Colombian market and distinctions from a traditional market that may play a role in the establishment and successful operation of a free trade agreement. Subsequently, using an incrementalist policy analysis, the U.S.-Colombia Free Trade Agreement will be explored in context by highlighting the potential benefits and drawbacks of the arrangement. Finally, conclusions and recommendations will be drawn to guide policymakers on the negotiation of other such arrangements in the future.

\section{THE USE OF BILATERAL TRADE AGREEMENTS AS PUBLIC POLICY}

Trade policy is one of the key components of any effective foreign policy. The establishment of beneficial trade relationships can facilitate domestic growth and industry expansion, while simultaneously promoting the development of an efficient global marketplace. Bilateral free trade agreements offer each country a set of particular benefits that will, in theory, increase their position as an exporter to the other party, among other things. These benefits generally include reduced tariffs and quotas on key products exported to the other country, which allow exporters to reduce overall costs.

The U.S. has the largest economy in the world, in terms of gross domestic product (GDP). Accordingly, it has the greatest economic influence and impact on other countries when negotiating trade agreements. The strong voices of the U.S. business community and industries such as agriculture and sugar have a substantial impact on the positions taken by the U.S. Trade Representative (USTR) ${ }^{7}$.

4 See US, Colombia reach free trade deal, WASH. POST, Feb. 27, 2006.

5 Id.

6 See also CARRANZA at 1032 (referring to the FTAA and suggesting that U.S. government and big business interests will have a unique opportunity to pry open the MERCOSUR market).

7 See, e.g., Stephanie Saul, Drug Lobby Got a Victory in Trade Pact Vote. N.Y. Times, July 2, 2005 (discussing the successful lobbying efforts of U.S. drug companies during the negotiations for the Central American Free Trade Agreement); see also, Chantal Thomas, For Democracy and Trade: The Case of the United States, 41 
The USTR has marketed free trade as a cure to the severe problems of poverty in many developing countries in which they are negotiating agreements ${ }^{8}$. The logic behind this idea comes from the widely held belief that economic growth spurs poverty reduction, and that free trade agreements bring economic growth ${ }^{9}$. However, several prominent scholars have concluded quite the opposite. Free trade may bring growth to certain sectors, but in the majority of cases, the developing country experiences a reduction in economic growth and an expansion of poverty ${ }^{10}$.

The exceedingly slow process of multilateral trade negotiations, such as that of the World Trade Organization, encourages developed countries such as the U.S. to meet its demand for better terms of trade through the use of smaller, less complicated bilateral and regional trade agreements. These agreements promise short-term gains in both trade access and political capital.

Powerful negotiators such as the U.S. have a vested interest in seeing economic growth and poverty reduction in developing countries because this creates more secure investment environments and increases the productivity of the world economy. However, if the policy of free trade and FTAs is failing to achieve these goals, it may be more appropriate to re-evaluate the policy and attempt to identify more effective mechanisms for achieving these goals. Thus, the next step in determining the effectiveness of FTAs as a public policy is to consider their impact on a developing economy.

\section{TRADE POLICY IN THE WESTERN HEMISPHERE}

\section{Brief Trade History of Latin America}

Latin American trade policies throughout the 1970s relied largely upon import substitution and infant industry protection, which involved significant State assistance for new industries and the promotion of industries which do not necessarily have a comparative advantage in trade ${ }^{11}$. The theory behind import substitution is that by limiting foreign imports of manufactured goods and replacing them with domestically produced goods, exports will begin to exceed imports and economic growth will occur ${ }^{12}$.

Harvard L. Rev. 1, 12.(describing the strong influence of industries in lobbying for benefits under U.S. trade policy).

8 See Press Release, United States Trade Representative (USTR), Myth: Trade and the FTAA will Spread Poverty, Fact Sheet (Nov. 2003), available at www.ustr.gov (contending that free trade is "among the most powerful tools available to fight poverty".) [hereinafter "Trade Facts"].

9 ImF Working Paper, M. Ayhan Kose, Guy M. Meredith, Christopher M. Towe, How Has nafta Affected the Mexican Economy? Review and Evidence, April 2004, at 24-25.

10 See, e.g., Id. at 25.

11 See, e.g., Joseph Stiglitz and Andrew Charlton, Fair Trade for All: How Can Trade Promote Development 17-21 (Oxford University Press 2005).

12 See, e.g., WERNER BAER, Import Substitution and Industrialization in Latin America: Experiences and Interpretations, 7 Latin Am. Res. Rev. n. ${ }^{\circ}$ 1, 95 (1972). 
Many countries in Latin America believed that adhering to the traditional theory of comparative advantage would require reliance on certain advantageous commodity exports that were not growing as quickly as other commodities in which they did not possess these same advantages ${ }^{13}$. Resulting growth in the region during the 1970 s confirmed the wisdom of these policies; however, growth fell to nearly zero in the 1980s while Asian countries, which relied on a theory of export promotion rather than import substitution, grew rapidly ${ }^{14}$. During this period, per capita income in Latin America declined by ten percent ${ }^{15}$.

Some researchers argue that the reason for the Latin American economic stagnation during the 1980s was the failed policy of import substitution. However, Joseph Stiglitz argues that this is not likely the case because, despite different trade policies in each country, economic stagnation occurred across the region ${ }^{16}$. Rather, STIGLITZ suggests that it was the openness of the Latin American economy to Foreign Direct Investment (FDI) and reliance on foreign capital goods that led to an increased debt burden and a resulting economic shock ${ }^{17}$. The protectionist policies of East Asia along with their export promotion were part of the reason that the region grew so rapidly ${ }^{18}$. This dependence on foreign capital combined with domestic markets, unprotected from foreign imports, resulted in stagnant, if not negative growth in Latin America.

Colombia maintained an import substitution policy since the late 1950s. Only in 1991 did Colombia begin to reduce its trade barriers and engage in regional trade agreements ${ }^{19}$. These agreements had been developing throughout South America since around 1980, when countries began to abandon trade protectionist policies and began to open their economies ${ }^{20}$. In 1993, the Andean Community was formed. This FTA was made up of Colombia, Venezuela, Ecuador and Bolivia and maintained a 2005 population of roughly 118 million people with a GDP of $\$ 650$ billion $^{21}$. Several of the remaining South American countries, including Brazil, Argentina, Paraguay and Uruguay, joined earlier to form Mercosur in $1991^{[22]}$. As the third largest trading bloc in the world ${ }^{23}$, and with 235 million people and $\$ 2.05$ trillion in GDP, Mercosur is a powerful force in shaping relations between Latin America and the rest of the world ${ }^{24}$.

15 See Peter Hakim, Western Hemisphere Free Trade: Why Latin America Should Be Interested, 526 Annals of the Am. Acad. of Pol. and Soc. Sci. 121, 123 (Mar. 1993).

16 STIGLITZ at 22.

17 Id.

18 Id.

19 See Diego Agudelo, Galia J. Benitez and Larry Davidson, Regional and Global Integration in South America: A Spanish Fiesta Within Trade Communities, Indiana Univ. Center for International Business Education \& Research, 7 (July 2005). See Id. at 2, 4 . Id. at 7 . See Id. at 7 (noting that Bolivia and Chile are also associate members of Mercosur). See Id. at 7-8.

Note that Venezuela has recently notified the Andean community of its intended withdrawal from the group. See, e.g., Venezuela's Withdrawal from Can Prompts Worries, LatinNews Daily, April 21, 2006, at 1; but, 


\section{FTAA Negotiations}

The Free Trade Area of the Americas (FTAA) was first negotiated in 1998 at the Second Summit of the Americas in Santiago, Chile. The intent of the agreement initially was to expand the North American Free Trade Agreement (NAFTA) throughout the Western Hemisphere by making a broader free trade zone ${ }^{25}$. This zone would encompass approximately 800 million people ${ }^{26}$. However, the Washington Consensus ${ }^{27}-$ a term used to describe the export of free trade policies and liberal reform from the U.S. - had been broadly opposed throughout Latin America, making the negotiation of a regional trade agreement challenging ${ }^{28}$. According to Dr. MARIO CARRANZA, "[m]ost people in the region feel that two decades of neoliberal policies have done little to alleviate poverty in Latin America"29.

Because of the economic and political power of Mercosur, issues of concern to the group must be addressed in any multilateral trade talks. Two primary issues were raised by Brazil at the FTAA talks - the Singapore issues and U.S. agricultural subsidies. The "Singapore issues" comprise a group of four issues of concern to developed countries but of little value and potential detrimental effect to developing countries. These issues are investment, competition, transparency, and government procurement. The proposed rules on foreign investment and competition policy could potentially prevent developing countries from importing technology and may give U.S. and European multinational businesses substantially more status in developing countries than a domestic business ${ }^{30}$. Named for their negotiation at the World Trade Organization (WTO) Singapore ministerial meeting in 1998, this set of issues largely led to the breakdown of the 2003 Cancun meeting of the $\mathrm{WTO}^{31}$.

The more substantial sticking point for continued trade negotiations involves the demand for the U.S. to eliminate its agricultural subsidies, which provide roughly $\$ 20$ billion in direct assistance ${ }^{32}$ to a farming sector comprising roughly $1 \%$ of the U.S. economy (see table 1$)^{33}$. Brazil demanded that the U.S. reduce agricultural subsidies as a condition of the FTAA, and the U.S. refused, stating instead that it would negotiate these subsidies

see Chavez Says Venezuela Willing to Reconsider Exit From CAN, BBC Monitoring International Reports, April 24, 2006.

See CARRANZA at 1030 .

See AGUDELO at 9.

27 This term, originally coined by JOHN WILLIAMSON, is also called neoliberalism and often refers to the process of globalization.

28 See CARRANZA at 1047-48 (discussing the backlash resulting from the implementation of the Washington Consensus throughout the 1990s).

29 CARRANZA at 1049.

30 See CARRANZA at 1051-52.

31 See World Trade Talks Collapse, BBC News, Sept. 15, 2003.

32 See, e.g., Chris Edwards and TAD DeHaven, The Stubborn Seeds of U.S. Farm Subsidies, the CATO Institute (Aug. 2001).

33 See, e.g., Economist Intelligence Unit Country Commerce Report: United States (May 2005). 
as part of the Doha round of world trade negotiations ${ }^{34}$. The failure of the parties to reach agreement on these two issues largely led to the breakdown of the negotiations ${ }^{35}$.

TABLE 1: PERCENTAGE OF OVERALL ECONOMY IN AGRICULTURE: UNITED STATES, COLOMBIA AND BRAZIL

United States
$\begin{aligned} & \text { The economy at a glance } \\ & \% \text { of estimated 2004 GDP }\end{aligned}$

The economy at a glance

$\%$ of 2004 GDP

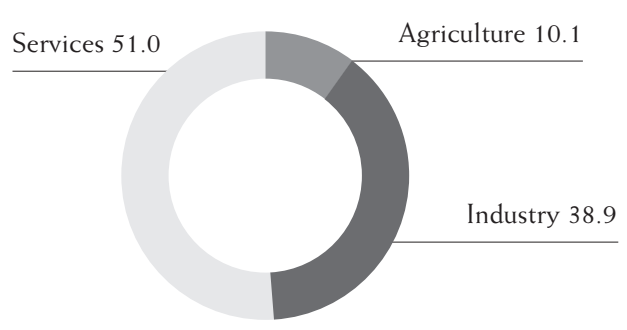

Fiscal year: January 1 st- December 31 th

Source: Economic Intelligence Unit, Country

Forecast Brazil, June2005.

Data from the Economist Intelligence Unit (2005).

The WTO Doha ministerial meeting was held in November 2001 and set an aggressive agenda focused on development issues as they relate to trade ${ }^{36}$. This meeting established

34 See, e.g., CARRANZA at 1051.

35 See CARRANZA at 1052-53.

36 The Doha round was the fourth official high-level ministerial meeting since the 1995 establishment of the World Trade Organization. The most recent ministerial meeting was held in Hong Kong in 2005. 
working groups and an agenda for all member states to address at future ministerial meetings, which are held at least every two years. The U.S. intended to address subsidies in the context of this agenda rather than in a regional trade negotiation because they sought equivalent subsidy reductions from the European Union, which would only happen in the context of multilateral trade negotiations ${ }^{37}$. However, there was industry-support for addressing the subsidies issue as part of the FTAA negotiations and economic surveys appeared to show an overall beneficial result to U.S. agriculture upon the elimination of subsidies in the FTAA region ${ }^{38}$.

There was strong support for the FTAA in many parts of Latin America, including those countries that objected to certain provisions regarding subsides and the Singapore issues. For instance, the Brazilian Ambassador to the U.S., Rubens A. Barbosa, released a statement calling for the restart of the FTAA negotiations. He said:

The ultimate goal of the process is not free trade for its own sake, but rather achieving the technological, economic, social, developmental, and political gains that we believe an FTAA can help generate.

These benefits will not emerge automatically, nor as an inevitable corollary of increased trade liberalization, but instead will require a balanced and equitable process of give and take ${ }^{39}$.

The most recent Summit of the Americas to discuss the conclusion of an FTAA was held in Argentina in November 2005. At that summit, approximately 29 nations supported the conclusion of an FTAA; however, the five opposing nations constitute the bulk of Mercosur and possess control of nearly half of all Latin American trade ${ }^{40}$. The latter group inserted language into the final agreement stating that the "conditions do not exist to attain a hemispheric free-trade accord that is balanced and fair with access to markets free of subsidies and distorted commercial practices ${ }^{\prime \prime 1}$. As a result, the talks broke down and President Bush departed the summit before it concluded ${ }^{42}$.

The FTAA as proposed in Santiago was dead. Yet the interest of the U.S. in securing trade agreements in the region was not. Strong support for some type of agreement by

Meetings are mandated to be held every two years. See, e.g., Ministerial Conferences, World Trade Organization, available at www.wto.org.

37 See, e.g., Colin MCMahon, Dissent Stalls Goals of Trade Talks: Busb Leaves Summit Without Agreement, CHI. TRIB., Nov. 6, 2005.

38 See, e.g., Remy JuREnAS, Agriculture in the Free Trade Area of the Americas, Congressional Research Service (June 15, 2004).

39 Press release, Rubens A. Barbosa, Brazilian Amb, to the U.S., Brazil and the United States: Overcoming Obstacles to an FTAA, available at http://www.brasilemb.org/embassy/embaixador_ftaa.shtml.

40 See, e.g., GarRY LeECH, Despite FTAA Defeat at Americas Summit, Free Trade to be Imposed on Colombia, Colombia Journal Online (Nov. 7 2005).

41 See Id.; see also, Summit of the Americas Fails to Resurrect FTAA, 9 Bridges Weekly Trade News Digest 38 (Nov. 9, 2005).

42 See LEECH. 
several Latin American countries led the U.S. to pursue bilateral FTAs with willing Latin American countries instead. The U.S. was never averse to the use of bilateral FTAs in the region $^{43}$. In fact, former U.S. Trade Representative (USTR) Robert Zoellick stated at the Miami ministerial meeting, "America will not wait for the won't-do countries [and will] move towards free trade with can-do countries" ${ }^{\prime 4}$.

Colombia's president, ALVARO URIBE, strongly supported President Bush in his push for a regional FTA. ${ }^{45}$ However, despite his political popularity, his position is not supported by a significant portion of the Colombian population ${ }^{46}$. Despite the lack of domestic support, President URIBE pursued a bilateral agreement with the U.S. A final agreement was signed on February 27, 2006.

The U.S. was intent on securing a trade agreement with Latin America in some form. The implementation of an FTAA in Latin America would allow the U.S. in effect to consolidate "its political and economic relevance in the world system" ${ }^{47}$. Some authors have contended that the use of bilateral trade agreements in Latin America of late has been the result of a failure to secure a multilateral FTAA ${ }^{48}$. If this is the case, the U.S. may still be able to reach its goal of reasserting its power in the hemisphere using the incremental process of signing bilateral FTAs ${ }^{49}$.

Colombia's primary trade partner outside of South America is the United States, accounting for approximately $40 \%$ of all export trade ${ }^{50}$. Accordingly, Colombia has significant interests to protect with regard to tariff and quota rates for Colombian exports to the U.S. In addition, Colombia does not have a highly diversified economy, resulting in part from their dependence on the U.S. as its primary trading partner, leaving few alternative markets offering sufficient demand ${ }^{51}$. However, Colombia will only pursue a trade agreement with the U.S. if they can be assured of actual economic and political gains. The U.S. was ready to offer these benefits, "but only after [Latin American countries] were able to shape up their own economies and get them on the road to recovery

See, e.g., CARRAnZA at 1054 (arguing that, at the Miami ministerial meeting, the U.S. stated its intent to pursue bilateral agreements with Bolivia, Colombia, the Dominican Republic, Ecuador, Panama and Peru, along with the FTAA itself).

Robert B. Zoellick, America Will Not Wait for the Won't-do Countries, Fin. Times, Sept. 22, 2003, at 23.

45 See, e.g., JANE BuSSEY, Trade negotiations are everywhere, but can they reach fruition?, For. Pol. (Jan. 1, 2005).

46 See, e.g., LEECH (finding that $43 \%$ of Colombians are opposed to an FTA with the U.S. and $38 \%$ support such an agreement).

47 See Agudelo, et al., at 10 .

48 See, e.g., CARRANZA at 1036 ("Bilateral free trade agreements...such as the one signed with Chile on June 6, 2003, would allow the United States to obtain concessions from individual countries without going through the cumbersome FTAA process".)

49 The U.S. is also involved in the political sphere of Latin American relations. One of the stated rationales for the U.S. to enter a bilateral FTA with Colombia is to combat drugs. See Remarks by Sec. Rice and Colombian Foreign Minister Barco (April 27, 2005) ("we spoke about the free trade agreement [with Colombia] and how important this is in its connection to combating drugs for Colombia".)

50 See Colombia Country Report, Economist Intelligence Unit (2005); see also AgUDELO et al., at 12, GRACIA at 8 .

51 AGDUELO et al., at 14 . 
and steady growth" ${ }^{\prime \prime 2}$. As a stable, democratic, middle-income country, Colombia is a viable beneficiary.

\section{POLICY ANALYSIS OF AN FTA BETWEEN COLOMBIA AND THE U.S.}

Political decision-making in the domestic arena is often brought about by the efforts of lobbyists, active political representatives, community organizations and other members of civil society that have a vested interest in moving change forward. When addressing issues of foreign affairs, influential parties are expanded to include foreign governments, international organizations, and federal agencies with an interest in trade, security or diplomacy.

Accordingly, making substantial decisions in the context of foreign affairs, such as eliminating agricultural subsidies, invading a sovereign nation or joining the International Criminal Court, require vast amounts of political capital and negotiating. International trade is an area that can be approached either from a grandiose perspective, i.e., WTO agreements, or from a smaller, more direct approach, i.e., bilateral trade agreements. The latter approach, which might be termed the incremental approach ${ }^{53}$, may be more effective in securing short-term benefits and maintaining sufficient political capital for a politician to stay in office. The broad, multilateral approach takes substantial political capital in the form of multiple trade negotiations and time spent securing beneficial arrangements, and is unlikely to achieve major success in the short time a politician remains in office. The incremental approach offers some hope of economic gain at a lower political capital price tag.

The approach of incremental change was presented in 1963 by DAVID BRAYBROOKE and Charles E. LindBLOM ${ }^{54}$. They suggest that while policymakers desire substantial change and the gathering of complete information about a proposed policy, they often accomplish neither and have to resort to a smaller, less informed way forward. Incremental decision-making "is decision-making through small or incremental moves on particular problems rather than through a comprehensive reform program ${ }^{\prime \prime 5}$.

BRAYBROOKE and LINDBLOM reject as naïve the synoptic model that tries to rationally order priorities in policymaking and argue that a welfare-function method that tries to identify the best possible solution to a problem is practically impossible, despite its desirability ${ }^{56}$. Instead, the authors incorporate their model of "disjointed incrementalism" as a reflection of the existing and in fact the best possible method of problem-solving in the policymaking process.

53 See David Braybrooke and Charles E. Lindblom, A Strategy of Decision: Policy Evaluation as a Social Process 71 (The Free Pres of Glencoe 1963).

54 Id.

55 Id. at 71 .

56 See K.E. Boulding, Book Review: A Strategy of Decision, 29 Am. Soc. Rev. 930-931 (Dec. 1964). 
Their approach to policymaking lowers the grand hopes and expectations of policymakers and encourages them to establish realistic, objective goals that can be accomplished despite not having complete information. Yet rather than abandoning larger goals, this approach suggests that they can be achieved through a series of coordinated steps:

To pursue incremental changes is to direct policy toward specific ills - the nature of which is continually being re-examined - rather than toward comprehensive reforms; it is also to pursue long-term changes through sequences of moves $^{57}$.

The incremental approach avoids focusing on long-term stability or substantial goals and instead presents marginal gains as useful in moving toward greater goals while not immediately (if ever) achieving them ${ }^{58}$. For example, rather than incorporating equality into an income distribution model, the incrementalist would not generalize about the potential losses, knowing that values frequently shift at the margin, and instead would focus on avoiding "intolerable situations" 59 . Recognizing that objectives, goals and values change as policies move forward, this approach sets smaller, more achievable short-term goals that allow for the long-term targets to remain flexible ${ }^{60}$.

Despite the drawbacks and criticisms of this theory ${ }^{61}$, it appears to be a reflection of the current U.S. policymaking approach to trade agreements. A comprehensive and informed approach to trade agreements would be to abide by General Agreement on Tariffs and Trade 1994 (GATT) Article 24, which restricts the entry by member States into bilateral FTAs by requiring notification and sanctioning of any free trade agreement outside the purview of the WTO. By discouraging FTAs in favor of moving toward a multilateral trading system that is monitored and enforced by a neutral world body, the WTO seeks to equitably balance the treatment of all member states and to protect developing countries from being taken advantage of through inequitable FTAs. As of May 2003, 265 regional trade agreements (RTAs) were notified to the WTO. Of these, only two have been approved under Article 24 and remain active ${ }^{62}$. This trend indicates an unwillingness to pursue a comprehensive and informed approach, consistent with Braybrooke and Lindblom's assessment.

The U.S. has not abandoned its use of FTAs in favor of encouraging the growth of a multilateral trading system largely because it is time-consuming and not cost-effective to

See BRAYBROOKE and LINDBLOM at 74.

See Id. at 102-03.

Id. at 103 .

60 Id. at 93-98.

61 See, e.g., Bernard Hennessy, Book Review: A Strategy of Decision: Policy Evaluation as a Social Process, 17 W. Pol. Q. No. 3, at 545-47 (Sept. 1964) (arguing that this theory fails to add anything to the field of political science and is perhaps more of a philosophical examination of a well-known process).

62 See T.N. SRINIVASAN, Regionalism and the World Trade Organization: Is Non-Discrimination Passé?, Center Discussion Paper No. 767 at 4 (Dec. 1996), citing WTO (1995) Regionalism and the World Trading System, Geneva: World Trade Organization; see also comments from JULIO LACARTE at WTO at 10 conference, New York (January 2006) (on file with author). 
wait for the effective functioning of a multilateral system ${ }^{63}$. Achieving consensus among 150 member states to implement such a comprehensive trading regime on tariffs, subsidies, and other key trade areas, has resulted in a slow moving and often stalled process of multilateral negotiations. BTAs and RTAs function as a shortcut to the achievement of freer trade.

Yet it is not only the speed of achieving consensus on a multilateral trade regime that has caused many countries to seek FTAs outside the WTO regime. At a recent WTO conference, MARI ELKA PANGESTU, Indonesia's Minister of Trade, said that while developing country trade ministers are well aware of the better terms of trade that they could achieve in a multilateral trading regime and while they know that FTAs are almost always negative for developing countries, pressure from businesses in their own countries force them to conclude some type of agreement that provides at least limited benefits to their industries ${ }^{64}$. Returning home without some type of trade agreement may reduce industry support for the ruling party.

The result of a desire to move forward, even if only in small steps, and the recognition that, while a better system may exist, more immediate results are better for maintaining political capital, is a process of disjointed incrementalism. In the context of international trade, an area to which BRAYBROOKE and LINDBLOM may not have predicted the application of their theory, the benefits and drawbacks of an incremental approach applied through FTAs between developed and developing countries may offer short-term political capital, but may also develop substantially inequitable economic conditions and thus long-term political disaster, at least for the developing country party.

\section{BENEFITS OF THE TRADE AGREEMENT}

The ATPA provided Colombia with duty-free access to the vast majority (approximately $80 \%$ ) of Colombian goods coming into the U.S. ${ }^{65}$. The ATPA benefits were set to expire at the end of 2006. Under the newly negotiated bilateral agreement, most of these trade preferences are made permanent. The primary exception to the agreement is the export of Colombian sugar, which will still face tariffs and quota restrictions in the U.S. "Any exports [of sugar] beyond the TRQ would face prohibitively high tariffs" 66 .

Colombia will open its previously closed market to the import of U.S. remanufactured goods, including machinery, computers and cellular phones ${ }^{67}$. Colombia will also

63 See comments of Timothy Punke, Preston Gates Ellis llp, at the American Bar Association Section of International Law Annual Meeting, Chicago, April 2006 (on file with author).

64 See comments of MARI ElKa PANGESTU, Minister of Trade, Republic of Indonesia, at the WTO at 10: Governance, Dispute Settlement and Developing Countries conference, New York, April 5-7, 2006 (on file with author).

65 See, e.g., "U.S. Announces Completion of Free-Trade Agreement with Colombia", U.S. Dept. of State (February 27, 2006).

66 Id.

67 Id. 
provide immediate duty-free treatment to U.S. farm exports, including beef, pork, corn, poultry, rice, fruits, vegetables, processed foods and dairy products ${ }^{68}$. Further, Colombia will provide immediate duty-free treatment to U.S. textiles, presuming that they meet the rules of origin under the agreement, although an escape clause was added to protect Colombian producers in the event that domestic Colombian producers are harmed by excessive imports ${ }^{69}$.

In the services sector, Colombia plans to offer more opportunities for market access, to the U.S. service industry including the dismantling of investment barriers as well as removal of the requirement that a branch be established in Colombia before services are provided $^{70}$. These benefits particularly go to the U.S. construction, energy and professional services industries ${ }^{71}$. In addition, telecommunication networks in Colombia are to be exposed to broader market openness through the removal of the ability of local firms to claim "first right" to the telecom networks ${ }^{72}$.

U.S. investors in Colombia will have an opportunity to operate in a more stable legal framework under the agreement. All types of investments are protected under the agreement, including enterprise, debt, concessions and intellectual property ${ }^{73}$. For the most part, U.S. investors will be treated as if they were Colombian investors, with the ability to establish, acquire and operate investments throughout the country ${ }^{74}$. They will also be provided with due process protections and remedies in the event of legal claims such as expropriation by the State ${ }^{75}$.

For intellectual property protections, U.S. companies will be treated equally with Colombian companies. Colombia agreed to develop an online trademark registration system, to extend the terms of copyright protections, to limit the grounds for revoking a patent and to create a system for preventing the marketing of pharmaceutical products that infringe patents ${ }^{76}$. Colombia is also required to ensure the use by the government of only legitimate computer software and to criminalize end-user piracy (such as with the illegal downloading of music $)^{77}$.

Colombian laws and regulations will be posted on the Internet under the agreement, providing procedural certainty and transparency. Laws will also be established to prohibit anti-competitive business conduct, enforce domestic labor laws, enforce environmental laws and to establish dispute settlement panels that promote compliance through trade- 
enhancing remedies ${ }^{78}$. Finally, the agreement includes "innovative provisions that allow the creation of working groups to evaluate the impacts of the agreement on small and medium-sized businesses" ${ }^{119}$.

\section{DRAWBACKS OF THE TRADE AGREEMENT}

\section{Agriculture}

One of the primary Latin American objections to the FTAA was the refusal of the U.S. to negotiate its position on agricultural subsidies. The importance of this issue to the region cannot be overstated ${ }_{i}$ however, the importance of this issue to each individual country in Latin America resonates unequally ${ }^{80}$. The U.S. - Colombia FTA did not address U.S. agricultural subsidies, nor did it seem likely to address them in other bilateral FTAs ${ }^{81}$.

The agreement is highly favorable to certain U.S. agricultural industries, including the beef, cotton, and wheat industries. These agricultural sectors will largely receive immediate duty-free access to the Colombian market ${ }^{82}$. According to negotiators, agricultural issues were the reason for the delayed conclusion of an agreement ${ }^{83}$. Strong opposition from most sectors of the Colombian agriculture industry was unsuccessful in slowing or preventing the progress of the agreement ${ }^{84}$.

Rice, sugar and poultry are three of the most sensitive agricultural products to the Colombian economy. Colombian negotiators sought to receive expanded duty-free access to the U.S. market for sugar in the range of 500,000 to one million additional tons per year. U.S. negotiators sought to protect the interests of the U.S. domestic sugar industry, which argued that Colombian access to the U.S. sugar market would triple in the first year, negatively impacting the U.S. sugar industry ${ }^{85}$. The resulting agreement provided additional access to only 50,000 tons of Colombian sugar (for a total of 75,000 tons per year $)^{86}$. The quota on sugar will increase by 750 tons per year, however, the over-quota tariff is the only tariff in the FTA that will never be phased out.

The U.S. was interested in expanding access for domestic producers to the Colombian rice market, which had previously been highly restrictive. The result was an increased

78 Id.

79 Id.

80 For example, the Colombian agricultural sector is $12.5 \%$ of its economy, whereas in Brazil agriculture accounts for $10.1 \%$ of its total economy, and in Venezuela, it accounts for $4.9 \%$ of the total economy. See Economist Intelligence Unit Economic Indicators: Colombia (2005).

81 See, e.g., Jenalia Moreno, FtaA Trade Meeting: U.S. Adds 6 Players to Lean on Brazil; S. American Giant Puts Up Resistance, Hous. Chron., Nov. 19, 2003, at 1B, 10B (suggesting that the U.S. refusal to address subsidies in the FTAA context signals an unwillingness to negotiate in the bilateral context as well).

82 See, Trade Facts.

83 See, e.g., U.S., Colombia Sign Bilateral FTA, 10 Bridges Weekly Trade News Digest 7 (March 1, 2006).

84 See Id. (noting, however, that the Colombian flower industry is expected to benefit from this FTA).

85 See, Completed Colombia FTA Would Triple Sugar Access in the First Year, Inside U.S. Trade (March 3, 2006).

86 See, e.g., Doug Palmer, U.S., Colombia Reach Free Trade Deal, Wash. Post, Feb. 27, 2006. 
quota of 79,000 tons and tariff elimination phased in over 19 years ${ }^{87}$. This was a significant improvement over past treatment and was hailed by the U.S. rice industry as a success over Colombian opposition ${ }^{88}$.

Colombia agreed to open its market to U.S. exports of chicken leg quarters, despite strong opposition by Colombian poultry farmers ${ }^{89}$. The market will permit an initial quota of 26,000 tons to be imported and will phase-out all quotas within 18 years ${ }^{90}$. A representative from a Colombian poultry trade association argued that this provision could wipe out the Colombian poultry industry "in a couple of years"

\section{Dispute Settlement}

A mechanism for exporters to remedy certain trade disputes between countries is an invaluable facet of an effective trade agreement ${ }^{92}$. The U.S.-Colombia FTA includes a dispute settlement mechanism that allows for monetary remedies to force compliance with respect to the core obligations of the agreement ${ }^{93}$.

Article 24 of the GATT agreement discourages member states from entering into bilateral FTAs. One of the rationales for this article is that weaker countries in trade agreements should be protected through legitimate and fair dispute settlement mechanisms. Disputes that arise out of a trade agreement are likely to be resolved in favor of the dominant party to the agreement without such protections. Article 24 urges the use of a multilateral approach, allowing weaker countries to effect more equitable and enforceable settlements, as opposed to a bilateral scheme where the dominant country may be in a better position to benefit from trade imbalances.

In the case of the U.S.-Colombia FTA, the dispute settlement mechanism has not yet been utilized; however, as it was negotiated outside the multilateral framework between a dominant State and subordinate State, there is a possibility that inequitable trade practices will not be effectively resolved in favor of Colombia in some instances.

\section{Economic Growth \& the Informal Sector}

After the conclusion of the NAFTA agreement between the U.S., Mexico and Canada, Mexico encountered substantial economic problems. These included a reduction in manufacturing sector employment, a $10 \%$ average drop in industrial worker wages, and

87 See Id.

88 See Forrest LaWs, Colombia FTA Could Help Sell More U.S. Rice Western Farm Press, Mar. 17, 2006 (discussing the comments of the USA Rice Federation toward to the newly concluded agreement).

89 See, e.g., Colombia Seals Trade Deal with US, BBC NEWS, Feb. 27, 2006.

90 See PALMER.

91 See PALMER.

92 See, e.g., HAKIM at 132 (suggesting that a dispute settlement system would be among the most important benefits to a Latin American country entering a trade agreement with the U.S.).

93 See Trade Facts at 7. 
a growth spurt in the informal economy ${ }^{94}$. During the 1990s, a similar expansion of income inequality was seen in Colombia, largely due to an imbalance across economic sectors and an increase in wage premiums ${ }^{95}$.

Peter Hakim, president of the Inter-American Dialogue, argues that the benefits of free trade for Latin America depend on three factors, each of which varies based on the country: 1) amount of exports shipped to the U.S.; 2) level of import barriers in the U.S. faced by the particular country, and 3 ) contribution of exports to the country's economy ${ }^{96}$.

Colombian exports to the U.S. are $46 \%$ of total exports ( $\$ 8.8$ billion), and U.S. exports to Colombia are $22 \%$ of Colombian imports $(\$ 5.4 \text { billion })^{97}$. Total Colombian exports in 2005 accounted for $\$ 18.8$ billion out of an annual GDP that year of $\$ 118.1$ billion $^{98}$. As a result of an FTA with the U.S., Colombia's exports to the U.S. are expected to increase by roughly $4 \%$ or $\$ 600$ million $^{99}$. The resulting increase, while significant, is far less than the economic gains made by the Asian tigers, which export closer to $40 \%$ of their total GDP ${ }^{100}$.

One of the major concerns left unaddressed in trade negotiations is the impact of export-led trade development in the informal, or extralegal sector of a developing country. Consider, for a moment, a small business owner in the U.S. that makes a living knitting sweaters and selling them at flea markets in rural Pennsylvania. The impact of a U.S. trade agreement with any other country on this business owner, if they are aware of the agreement, will be either zero (because they are not an exporter of goods) or negative (because they face increased foreign competition from less expensive imported sweaters).

The small business owner in our example is usually unregulated and operating on a self-proprietary basis. They may or may not have a license, but likely do not participate in the formal economy that an orthodox store owner would. These businesses exist in the U.S., but on a comparatively small scale ${ }^{101}$. In many developing countries, these informal economies constitute as much as $80 \%$ of the total economy ${ }^{102}$. The World Bank estimates that Colombia's informal economy is $39.1 \%$ of total GDP ${ }^{103}$.

Returning briefly to our example, if the U.S. sweater manufacturer became aware of the new trade agreement and was interested in selling their wares to the country with which the agreement was signed, the process for acquiring a business and export license

94 See, GuY PoITRAS, Inventing North America: Canada, Mexico, and the United States, 125 (2001).

95 See Gracia at 6.

96 HAKIM at 126-128.

97 See Background Note: Colombia, U.s. Dept. of State, Bureau of Western Hemisphere Affairs (Feb. 2006) (explaining that Colombian exports to the U.S. totaled us $\$ 8.8$ billion in 2005).

98 See Id.

99 See HAKIM at 128.

100 Id. 128.

101 The World Bank estimates the U.S. informal economic sector to be $8.8 \%$. See, World Bank, Doing Business (2003).

102 See Hernando de Soto, The Other Path: The Economic Answer to Terrorism XVI (Basic Books 1989).

103 World Bank, Doing Business (2003) 
would be easier, faster and less expensive than is the case in most developing countries. The World Bank estimates that it would take about five days, with an average of five steps and would cost $0.5 \%$ of annual per capita GDP to start a formal business in the U.S. ${ }^{104}$. In Colombia, the same manufacturer would go through twelve steps, taking roughly 43 days and costing $25.3 \%$ of annual income.

Acquiring the licenses to operate and complying with permit requirements for our U.S. manufacturer would take about 70 days and cost $16.9 \%$ of income per capita. The same business in Colombia would require 150 days and cost $697.3 \%$ of income per capita to comply ${ }^{105}$. Finally, the time it takes to export goods once the business has been legally registered and licensed, is nine days in the U.S. and 34 in Colombia ${ }^{106}$. Thus, while the U.S. sweater manufacturer may survive the wait and could potentially benefit from the agreement, a typical Colombian exporter may face significant challenges in getting their goods to foreign markets and thus would be less likely to benefit from the agreement.

TABLE 1: COMPARISON OF THE TIME TO BEGIN AN EXPORT OPERATION IN THE U.S. AND COLOMBIA

Days to Start an Export Business

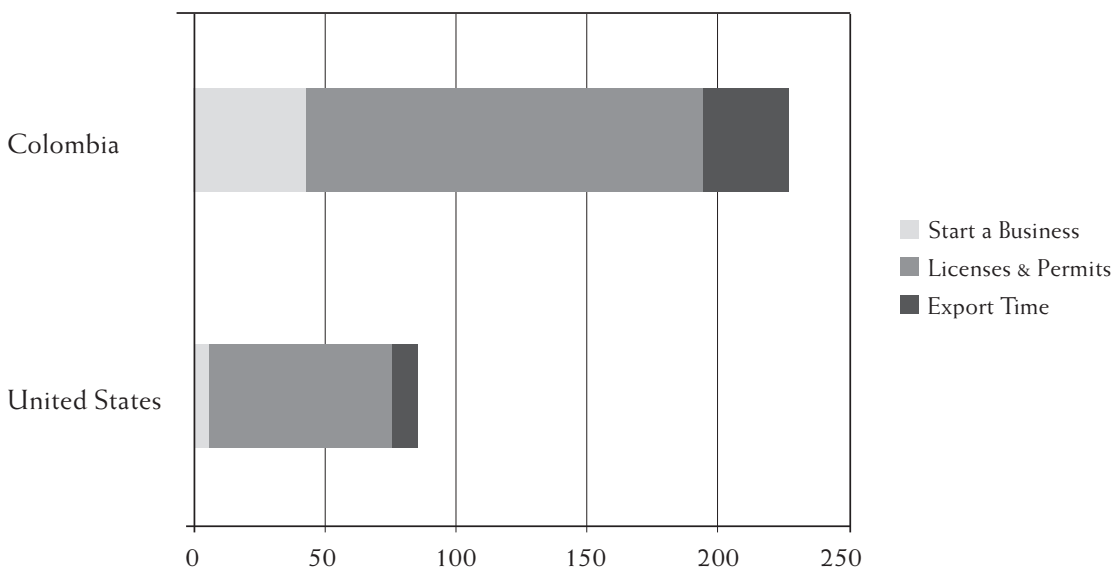

Data from World Bank, Doing Business (2003) 
Costs of Starting an Export Business

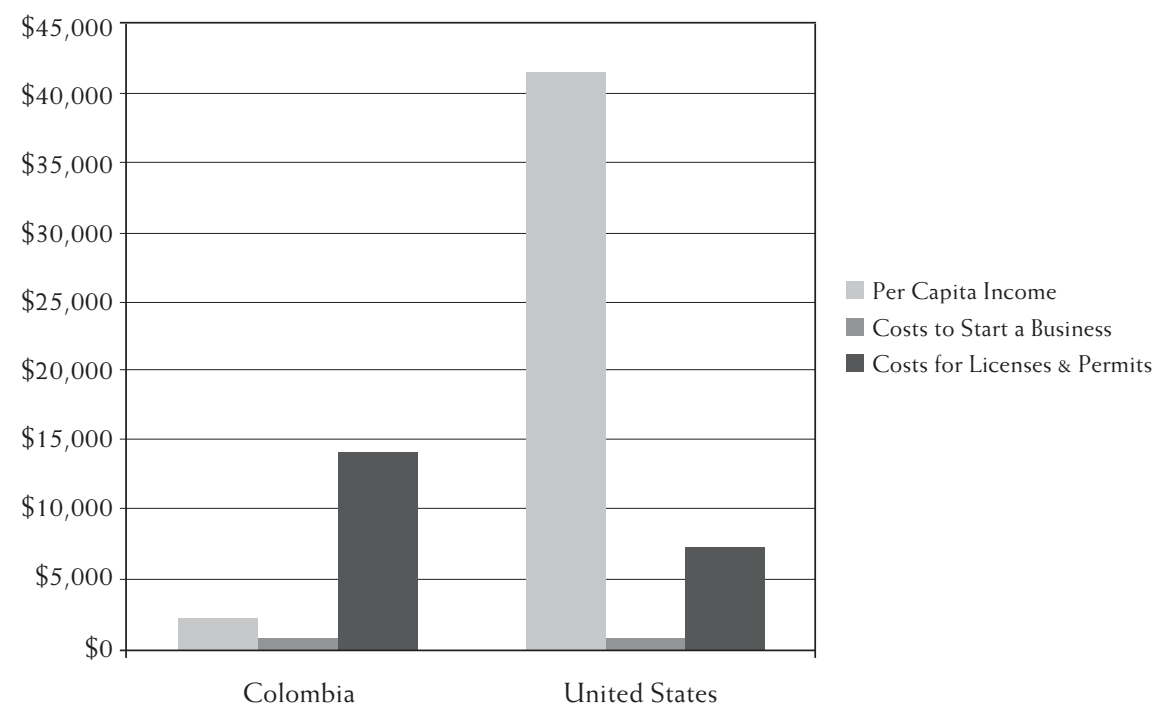

Data from World Bank, Doing Business (2003).

The distinction between the benefits accruing to an informal economic businessperson in the U.S. and that same businessperson in Colombia are stark. Yet more importantly, the scope of this impact is much greater in Colombia with almost half of their entire economy unable to easily and affordably benefit from the FTA. Accordingly, the impact on economic growth must be analyzed very differently based upon the parties to the agreement.

Inequitable trade results when economic benefits from trade accrue to one segment of society and either have no effect or a negative effect on other segments of society. When a segment of society is excluded from the export economy due to an inability to operate their business legally, any export-driven benefits acquired through an FTA will accrue disproportionately to the population. The income gap among the Colombian population may grow because of this FTA as a result of increased export benefits for Colombia's legal exporters combined with the negative impact of increased competition from U.S. imports on extralegal businesses throughout Colombia.

\section{Conclusions and Recommendations}

Colombia and other South American countries have an alternative to forming either an FTAA or entering potentially detrimental bilateral agreements with other countries. A unification of Mercosur with the Andean Community would create a significant force in the Western hemisphere and in the world and may serve as an adequate substitute for 
the conclusion of an FTAA $^{107}$. A regional approach to liberalized Latin American trade has the advantage of unifying related markets, each of which shares the goals of poverty reduction and equitable economic growth. Recent events in the region may make such regional unification difficult from a political standpoint, but it is in the best economic interests of each country to pursue a single approach to foreign trade for the region.

The effect of an FTA on Colombian economic growth is uncertain. According to an economic study conducted by Hernando ZuLETA and OSCAR Gracia, "the effect of an FTA [on Colombia] alone is likely to be relatively small"108. By and large, developing countries are importers of goods; accordingly, an FTA that lowers import barriers for a developed and a developing country has more positive economic impact on the developed country ${ }^{109}$. The impact of a bilateral trade agreement on Colombia may be less significant than FTAs in other parts of the world ${ }^{110}$.

As a growing middle-income economy, Colombia is approaching the road to economic independence and should tread carefully to avoid succumbing to a deeper dependency relationship with the U.S. Trade offers many developing countries opportunities to pursue economic growth strategies. However, it is not in the opening of markets where these opportunities lie. Rather, trade offers an opportunity to examine domestic policies on imports and exports, manufacturing, technological growth, as well as to evaluate rule of law protections for domestic producers and foreign investors, regulatory flexibility for licensing and innovation, and investment in domestic education and health programs ${ }^{111}$.

The short-term gain policy approach to trade agreements applied by the U.S. may serve short-term interests and appease certain business communities in both the U.S. and the partner country. However, this incremental approach suffers from a lack of foresight and ignores a deeper discussion about development and equitable trade, without which the global trading system will be less predictable, accountable and successful.

Critics have suggested that the incremental decision-making approach was part of the reason for the failed U.S. policy in Vietnam during the 1960 s and $1970 \mathrm{~s}^{112}$. Had a more comprehensive strategy been applied at the outset, significant lives may have been saved. Using this incremental approach to secure an FTA with Colombia may similarly

107 See, e.g., CARRANZA at 1052.

108 Orlando Gracia and Hernando Zuleta, The Free Trade Agreement Between Colombia and the USA: What Can Happen to Colombia?, Working Paper (2004), available at http://www.webpondo.org/filesoctdic2004/fta. pdf.

109 VICTOR MOSOTI, Bilateral Investment Treaties and the Possibility of a Multilateral Framework on Investment at the WTO: Are Poor Economies Caught in Between? 26 NW J. Int'l \& Bus. 95, 96-99 (Fall 2005).

110 See AgUDELO at 21 (inferring that globalization and trade agreements in general have less impact in Latin America than they do in other parts of the world).

111 See, e.g., Peter HaKim, Western Hemisphere Free Trade: Why Should Latin America be Interested?, 526 Annals, 121 (March 1993) (suggesting that the economic and political restructuring resulting from free trade agreements is where the real economic benefits come from).

112 See, e.g., C. Boyden Gray, The War in Kosovo: Failed Lessons of Incrementalism, 34 Loy. L. R. 5, 6 (Nov. 2000) (finding that the use of incrementalism delayed the effective application of force in Vietnam through the use of the Reserves at the outset of the war). 
blind policymakers to the most salient trade issues in the region - namely, equitable economic growth policy, development assistance, and growth of social capital. The imbalanced trade resulting from this and similar FTAs further solidifies the inferior position of developing countries in the global marketplace. 